\title{
Effect of precooling on pain during local anesthesia administration in children: a systematic review
}

\author{
Sunny Priyatham Tirupathi', Srinitya Rajasekhar ${ }^{2}$ \\ ${ }^{1}$ Department of Pedodontics \& Preventive Dentistry, Malla Reddy Institute of Dental Sciences, Hyderabad, Telangana, India \\ ${ }^{2}$ Department of Pedodontics \& Preventive Dentistry, Malla Reddy Dental College for Women, Hyderabad, Telangana, India
}

\begin{abstract}
This study was conducted to determine how precooling reduces the subjective reported pain and objective pain and to evaluate the effectiveness of precooling the injection site before administration of local anesthesia in children. Electronic databases (PubMed, Ovid SP, Cochrane Central Register of Controlled Trials) were searched for publications from 1980 to 2020. Studies were screened for titles and abstracts, followed by full-text evaluation of included reports. Six studies were included in this systematic review. The primary outcome evaluated was the pain perception or the subjective pain reported by the child receiving the injection. The secondary outcome evaluated was objective pain evaluated in each study. Among 5 studies that evaluated child reported pain scores on a visual analogue scale (VAS), 4 studies reported lower scores in the precooling group and one study reported a higher VAS score in the precooling group than in children treated with $20 \%$ benzocaine topical anesthesia. Among 6 studies that evaluated the pain reaction of children by Sound Eye Motor (SEM) score, 4 studies reported a lower SEM score in the precooling group, one study reported no significant difference between the precooling and control groups, and one study reported higher SEM scores in the precooling group than in children treated with $20 \%$ benzocaine topical anesthesia. Within the limits of this systematic review, evidence suggests that precooling the injection site with ice can be an effective adjunct to topical anesthesia in reducing both subjective and objective pain during local anesthesia administration in children.
\end{abstract}

Keywords: Children; Local Anesthesia; Pain; Precooling.

This is an Open Access article distributed under the terms of the Creative Commons Attribution Non-Commercial License (http://creativecommons.org/licenses/by-nc/4.0/) which permits unrestricted non-commercial use, distribution, and reproduction in any medium, provided the original work is properly cited.

\section{INTRODUCTION}

Administration of local anesthesia is one of the most feared dental procedures by the patient [1]. The pain perceived during local anesthesia administration in children is mitigated by various methods such as application of topical anesthetics [2], camouflaging of the syringe [3,4], distraction with audio-visual glasses [5], modification of the local anesthetic solution [6,7], and counter-stimulation. Vibration, pressure application, and pre-cooling [8] are different types of counter-stimulatory measures to reduce pain perception during local anesthesia administration.

Although precooling is used for medical procedures such as venepunctures and immunizations, it has not been routinely used in dentistry [9]. Precooling with ice before palatal injection was first proposed by Henry Harbert in 1989 [10]. Duncan et al. reported on the effects of precooling with refrigerant spray for palatal injections in adults [11].

Kosaraju and Vandewalle compared a refrigerant spray with administration of $20 \%$ benzocaine for evaluation of pain due to palatal anesthesia administration in adults and reported precooling with refrigerant spray to be an

Received: April 27, 2019 - Revised: May 8, 2020 - Accepted: May 12, 2020

Corresponding Author: Sunny Priyatham Tirupathi, Department of Pedodontics \& Preventive Dentistry, Malla Reddy Institute of Dental Sciences, Hyderabad, Telangana, India

E-mail: dr.priyatham@gmail.com

Copyright(c) 2020 Journal of Dental Anesthesia and Pain Medicine 
effective method for pain reduction of palatal anesthesia administration in adults [12]. Several authors reported iced-cotton bud to be an effective precooling agent for the reduction of pain during palatal anesthesia administration [13]. However, one study reported adverse effects in form of palatal necrosis due to the application of refrigerant spray for 10 seconds [14].

There are only few studies on the effectiveness of precooling in children. The present systematic review aims to evaluate the literature regarding the effectiveness of precooling before local anesthesia administration in children.

\section{METHODS}

\section{Protocol and registration}

Prospero-awaiting registration-acknowledgement-ID: 182283. This study is in accordance with the PRISMA guidelines.

The search strategy was conducted using the population, intervention, comparison, and outcome (PICO) framework, based on the following question. "Does precooling before local anesthesia administration have any influence on pain perception and pain reaction in children?" The PICO search strategy of the systematic review was as follows: $[\mathrm{P}]$ patient: children aged between 3 and 17 years; [I] intervention: precooling at the injection site before local anesthesia administration (infiltration, block, maxilla, or mandible); [C] comparison: No-precooling. [O] outcome of interest: subjective and objective pain.

Children aged between 3 and 17 years who were undergoing local anesthesia (supraperiosteal or block injections) were selected. The intervention consisted of precooling the injection site before local anesthesia administration. Controls were patients who received injections without precooling, or patients who received another form of intervention.

An electronic search was performed in three databases, namely PubMed, Ovid SP, and Cochrane. The search was conducted from publication year 1980 to 2020 . The last search was performed on 30 March 2020. Only Articles published in English were included. The search was based on the pre-specified question using relevant $\mathrm{MeSH}$ terms, ((((precooling) or cooling)) and ((anesthesia) or injection)) and dental.

\section{Eligibility criteria}

Randomized controlled clinical trials, in which precooling before local anesthesia administration was performed were included. Non- randomized studies or non-controlled clinical trials, comparative studies, technical notes, case reports, narrative reviews, and systematic reviews and articles articles that are not available in English were excluded. Studies combining precooling with other counter stimulatory methods were also excluded.

Initially, studies obtained after comprehensive MeSH terms search were imported to Zotero (www.zotero.org) from all the databases, and exclusion of duplicates was performed, and then a screening of titles and abstracts was carried out. Potential articles were then included for a full review. Data extraction and data analysis was performed by two independent reviewers and was recorded on excel. The data contained information regarding author names and year of publication, study design, number of participants, age, intervention, control, and outcome. The primary outcome measure sought for was "Pain perception," i.e., self-reported pain score of children measured by the visual analog scale (VAS). Secondary outcome included was "Pain reaction" i.e. pain observed and scored by the operator was measured with sound, eye, and motor scale (SEM). Means and standard deviations were collected from individual studies.

\section{Data synthesis}

Data (mean and SD) of VAS and SEM was not reported in most of the studies, hence only qualitative analysis of selected studies was performed. 
Table 1. Excluded studies with reasons

\begin{tabular}{cll}
\hline No. & \multicolumn{1}{c}{ Excluded articles } & \multicolumn{1}{c}{ Reason for Exclusion } \\
\hline 1. & Bilsin 2020 [15] & Extra-oral cooling used along with vibration \\
2. & Jayasuriya $2017[13]$ & Technical note and not a randomized trial \\
3. & Bhadauria 2017[16] & Study is on adult subjects \\
4. & Johnson 2003[17] & Adult subjects with palatal mucosa \\
\hline
\end{tabular}
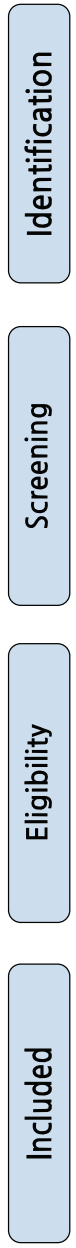

Flow Diagram

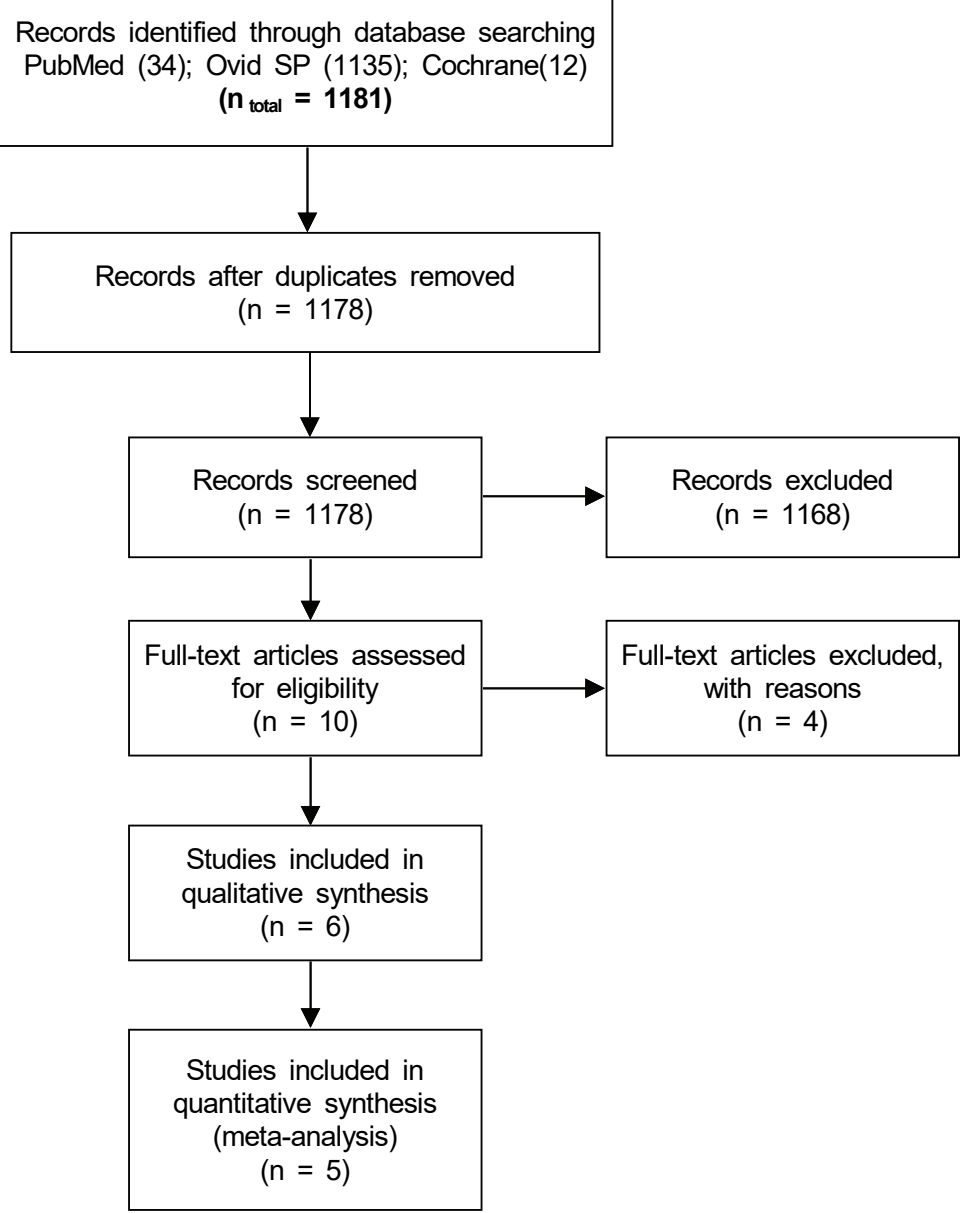

Fig. 1. PRISMA 2009 flow diagram

\section{Risk-of-bias assessment}

The methodological quality assessment of the included articles was conducted independently by two review team members using the Cochrane Collaboration's criteria. Quality of all selected trials was assessed for risk of bias under seven domains: sequence generation, allocation concealment, blinding of participants and personnel, blinding of outcome assessment, completeness of outcome data, selective reporting of outcomes, and other sources of bias. Studies with seven domains of low bias risk were classified into a low risk of bias group. If one or more domain presented a high risk of bias, these studies were categorized as having high risk of bias; otherwise, the study was categorized as having unclear risk of bias. 
Table 2. Characteristics of Included studies

\begin{tabular}{|c|c|c|c|c|c|c|c|c|c|c|c|c|}
\hline Sno & Author-year & Study design & $\begin{array}{c}\text { Sample } \\
\text { characteristics }\end{array}$ & $\begin{array}{l}\text { Type of } \\
\text { injection }\end{array}$ & $\begin{array}{c}\text { Intervention } \\
\text { characteristic and } \\
\text { comparison groups }\end{array}$ & $\begin{array}{l}\text { Coolant } \\
\text { used }\end{array}$ & $\begin{array}{c}\text { Duration of } \\
\text { precooling } \\
\text { injection site }\end{array}$ & $\begin{array}{l}\text { Needle } \\
\text { gauge }\end{array}$ & $\begin{array}{l}\text { Measuring } \\
\text { Scales }\end{array}$ & SEM & VAS & Outcomes \\
\hline 1. & $\begin{array}{l}\text { Vafaei } 2019 \\
\text { [18] }\end{array}$ & $\begin{array}{l}\text { Randomized } \\
\text { trial } \\
\text { Split mouth } \\
\text { design }\end{array}$ & $\begin{array}{l}99 \text { Children } \\
\text { aged 6-10 years } \\
\text { G1: } 33 \\
\text { G2: } 33 \\
\text { G3: } 33\end{array}$ & $\begin{array}{l}\text { Buccal } \\
\text { infiltration- } \\
\text { maxillary } \\
\text { primary } \\
\text { molar }\end{array}$ & $\begin{array}{l}\text { G1: (n=33) counter } \\
\text { imitation versus } 20 \% \\
\text { benzocaine } \\
\text { G2: (n=33) Ice } \\
\text { precooling versus } \\
20 \% \text { benzocaine } \\
\text { G3: (n=33) } \\
\text { Refrigerant versus } \\
\text { 20\% benzocaine }\end{array}$ & $\begin{array}{l}\text { Ice and } \\
\text { Tetra-fluoro } \\
\text {-ethane }\end{array}$ & Not mentioned & 25 gauge & $\begin{array}{l}\text { VAS } \\
\text { SEM }\end{array}$ & $\begin{array}{l}\text { Mean and SD values were } \\
\text { not mentioned anwhhere } \\
\text { in the article. } \\
\text { Median SEM values for } \\
\text { benzocaine is } 4 \text {, ice } \\
\text { precooling group is } 5 \text {, } \\
\text { refigerant preccoling } \\
\text { group is } 6 \text {. }\end{array}$ & $\begin{array}{l}\text { Mean and SD values were } \\
\text { not mentioned anywhere } \\
\text { in the article. } \\
\text { Median VAS values for } \\
\text { benzocaine is } 1 \text {, ice } \\
\text { precooling group is } 2 \text {, } \\
\text { refrigerant preccoling } \\
\text { group is } 5 \text {. }\end{array}$ & $\begin{array}{l}\text { Benzocaine was better } \\
\text { compared to all the other } \\
\text { groups followed by } \\
\text { counter iritation by } \\
\text { vibration, ice precooling } \\
\text { group } \\
\text { loe precooling better than } \\
\text { refrigerant spray }\end{array}$ \\
\hline 2. & $\begin{array}{l}\text { Bose } 2019 \\
{[19]}\end{array}$ & $\begin{array}{l}\text { Randomized } \\
\text { trial } \\
\text { Split mouth } \\
\text { design }\end{array}$ & $\begin{array}{l}100 \text { Children } \\
\text { aged } \\
\text { 6-14 years } \\
\text { G1: } 50 \\
\text { G2: } 50\end{array}$ & $\begin{array}{l}\text { Infiltration } \\
\text { \& Block }\end{array}$ & $\begin{array}{l}\text { Total } 100 \text { Precooling } \\
\text { (no topical) } \\
\text { Total } 100 \\
\text { No-precoling } \\
\text { (no topical) }\end{array}$ & Ice & 60 seconds & $\begin{array}{l}\text { Not } \\
\text { mentioned }\end{array}$ & $\begin{array}{l}\text { VAS } \\
\text { SEM }\end{array}$ & $\begin{array}{l}\text { Mean and SD values were } \\
\text { not mentioned anwhhere } \\
\text { in the article. Wilcoxon } \\
\text { signed rank test was used } \\
\text { and rank score } \\
\text { Sound eye motor scores } \\
\text { were lower for precooling } \\
\text { compared to without } \\
\text { precooling (z- value }-3 \text {, } \\
-5.74,-2.23)(P-\text {-values } \\
\text { were } .003,000, .025) \text { for } \\
\text { SEM, respectively }\end{array}$ & $\begin{array}{l}\text { Mean and SD values were } \\
\text { not mentioned anywhere } \\
\text { in the article } \\
\text { VAS scores significantly } \\
\text { lower for precooding group } \\
\text { for both block injections } \\
\text { (Z score-4.974: } \\
\text { P value }<0.001) \text { as well } \\
\text { as inflitrations } \\
(Z \text { score }-5.49 \\
\text {; P value }<0.001)\end{array}$ & $\begin{array}{l}\text { Pre-Cooling better in } \\
\text { reducing pain for both } \\
\text { Infiltration and block }\end{array}$ \\
\hline 3. & $\begin{array}{l}\text { Hameed } 2018 \\
\text { [8] }\end{array}$ & $\begin{array}{l}\text { Split mouth } \\
\text { design }\end{array}$ & $\begin{array}{l}50 \text { Children } \\
\text { aged 8-10 years } \\
\text { 50- precooling } \\
\text { 50- lignocaine } \\
\text { spray }\end{array}$ & IANB & $\begin{array}{l}\text { G1: precooling only } \\
\text { G2: lignocaine spray } \\
\text { only }\end{array}$ & $\begin{array}{l}\text { Tetra-fluoro } \\
\text {-ethane }\end{array}$ & 10 seconds & 26 gauge & $\begin{array}{l}\text { VAS } \\
\text { SEM }\end{array}$ & $\begin{array}{l}\text { Mean and SD values were } \\
\text { not provided directly and } \\
\text { was calculated from the } \\
\text { table. Mean SEM for } \\
\text { Lignocaine group was } 1.42 \\
\pm 1.42 \text { and for ice } \\
\text { precooling group was } 1.2 \\
\pm 1.52 \text {. Not significantly } \\
\text { lower SEM scores were } \\
\text { observed in the precooding } \\
\text { group } \\
(P>0.05)\end{array}$ & $\begin{array}{l}\text { Mean and SD values were } \\
\text { not provided directly and } \\
\text { was calculated from the } \\
\text { table Mean VAS for } \\
\text { Lignocaine group } \\
2.14 \pm 1.34 \text { and ice } \\
\text { precooling group was } 1.52 \\
\pm 1.3 \text {. Significantly lower } \\
\text { VAS scores were observed } \\
\text { in precooling group } \\
(P<0.05)\end{array}$ & $\begin{array}{l}\text { Refrigerant precooling } \\
\text { better than lingo spray } \\
\text { (percentage } \\
\text { concentration of spray } \\
\text { not mentioned) }\end{array}$ \\
\hline 4. & $\begin{array}{l}\text { Ghaderi } 2013 \\
\text { [20] }\end{array}$ & $\begin{array}{l}\text { Randomized } \\
\text { trial } \\
\text { Split mouth } \\
\text { design }\end{array}$ & $\begin{array}{l}50 \text { children aged } \\
8-10 \text { years }\end{array}$ & $\begin{array}{l}\text { Buccal } \\
\text { infiltration } \\
\text { For maxillary } \\
\text { region }\end{array}$ & $\begin{array}{l}50 \text { - Precooling }+ \\
20 \% \text { benzocaine } \\
50-20 \% \\
\text { Benzocaine only }\end{array}$ & Ice & 60 seconds & 27 gauge & $\begin{array}{l}\text { VAS } \\
\text { SEM }\end{array}$ & $\begin{array}{l}\text { The mean SEM scores for } \\
\text { precooling group was } 4.06 \\
\pm 1.32 \text { and for control } \\
\text { group was } 5.44 \pm 1.79 \text {. } \\
\text { Significantly lower SEM } \\
\text { scores were observed in } \\
\text { the precooling group } \\
(\mathbb{P}<0.05)\end{array}$ & $\begin{array}{l}\text { The mean VAS scores for } \\
\text { precooling group was } 4.22 \\
\pm 1.27 \text { and for control } \\
\text { group waS } \\
5.84 \pm 1.68 \text {. Significantly } \\
\text { lower VAS scores were } \\
\text { observed in the precooling } \\
\text { group } \\
(P<0.05)\end{array}$ & Ice precooling was better \\
\hline 5. & $\begin{array}{l}\text { Lathwal } 2013 \\
\text { [21] }\end{array}$ & $\begin{array}{l}\text { Randomised } \\
\text { trial } \\
\text { Split mouth } \\
\text { design }\end{array}$ & $\begin{array}{l}160 \text { children } \\
\text { aged } \\
\text { 5-8 years }\end{array}$ & $\begin{array}{l}\text { Block } \\
\text { injection only }\end{array}$ & $\begin{array}{l}\text { G1: Ice vs } \\
\text { benzocaine } \\
\text { G2: Refigerant vs } \\
\text { benzocaine }\end{array}$ & $\begin{array}{l}\text { Ice and } \\
\text { Tetra-fluoro } \\
\text {-ethane }\end{array}$ & $\begin{array}{l}60 \text { seconds } \\
\text { with ice } \\
5 \text { seconds for } \\
\text { refrigerant } \\
\text { precooling } \\
\text { group }\end{array}$ & 25 gauge & $\begin{array}{l}\text { VAS } \\
\text { SEM }\end{array}$ & $\begin{array}{l}\text { The mean SEM scores for } \\
\text { precooling with ice group } \\
\text { was } 4.5 \pm 2.18 \text { and for } \\
\text { control group was } 5.40 \pm \\
\text { 2.13. Significantly lower } \\
\text { SEM scores were observed } \\
\text { in the precooling group } \\
(P<0.05) \\
\text { The mean SEM scores for } \\
\text { precoling with refigerant } \\
\text { group was } 5.4 \text { (SD not }\end{array}$ & $\begin{array}{l}\text { The mean VAS scores for } \\
\text { precooling with ice group } \\
\text { was } 2.4 \text { (SD not provided) } \\
\text { and for refigerant group } \\
\text { waS } 3.8 \text { (SD not provided) } \\
\text { and for control group waS } \\
4.0 \text { (SD not provided). } \\
\text { Intergroup comparison of } \\
\text { VAS scores between ice } \\
\text { precooling and refrigerant } \\
\text { precooling shows }\end{array}$ & $\begin{array}{l}\text { loe cone precooling better } \\
\text { than Refrigerant and } \\
\text { benzocaine }\end{array}$ \\
\hline
\end{tabular}




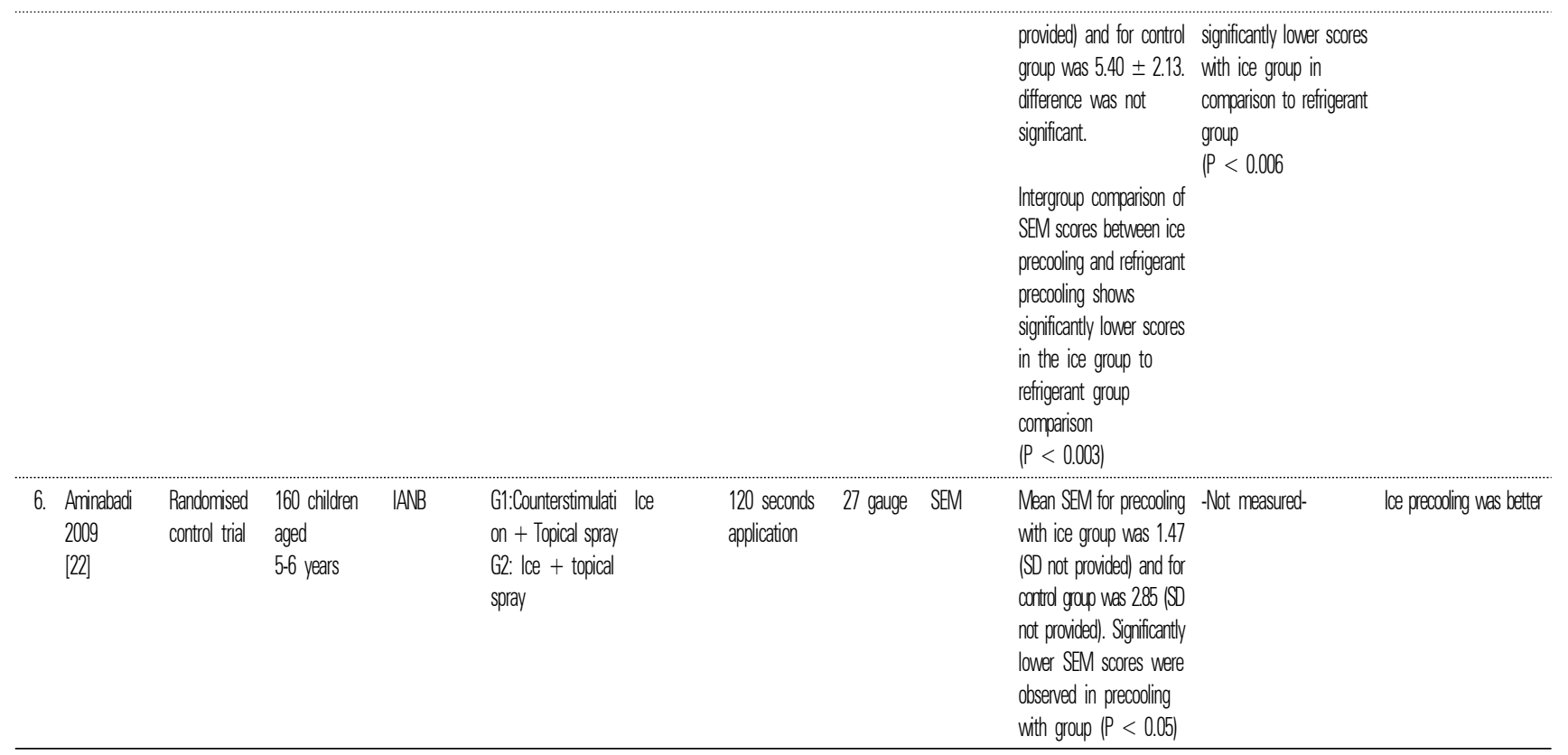

*Abbreviations used in this table: UB- FPR Scale, The Wong Baker FACES scale; VAS scale, visual analogue scale; SEM scale, Sound, eye, motor scale; G1, group 1; G2, group 2; G3, group 3

\section{RESULTS}

In all the databases, 1181 records were found, of which 3 were duplicates. After removal of the duplicate articles, a total of 1178 records were screened for title and abstract. Full texts of 10 potentially relevant papers were evaluated, of which 4 were excluded [13,15-17] (Reasons for exclusion is provided in Table 1). Consequently, 6 studies were included in this final systematic review [8, 18-22]. A flowchart of the search results is presented in Fig. 1.

Characteristics of included studies: The characteristics of the included studies are shown in Table 2. All the six studies published between 2009 and 2019 are split-mouth crossover trials [8,18-21], except one study, which is a randomized control trial [22].

Risk of Bias: Risk of bias (Fig. 2) was evaluated according to Cochrane guidelines. Randomization was mentioned in most of the studies $(n=5)$. Blinding of participants was not possible with these studies as precooling can be felt by the children. Blinding of outcome assessment was performed only in two studies $[18,22]$. Low risk of bias was found only for parameters

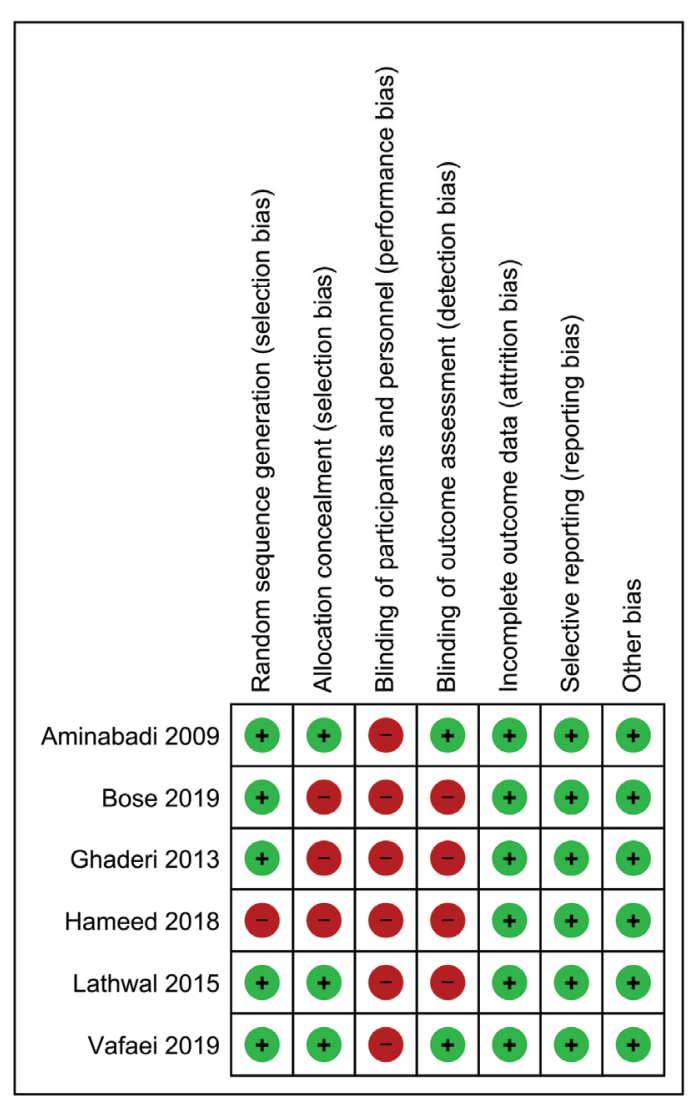

Fig. 2. Risk of bias summary

such as incomplete outcome data (attrition bias) and selective reporting (bias reporting) in all the included 
studies $(n=6)$. The overall risk of bias is high in all the included studies.

\section{DISCUSSION}

A total of 6 studies were included for the final review. Among them, 5 studies followed the split-mouth design [8,18-21] except the study conducted by Aminabadi and Farahani [22]. The age of the children in the included studies ranged from 5 to 14 years.

Only precooling of the injection site without the use of any topical anesthesia before local anesthesia administration was reported in 4 studies $[8,18,19,21]$. Precooling in combination with topical anesthesia (benzocaine) was used in 2 studies [20,22]. Precooling in all the included studies was achieved by using ice $[19,20$, $22]$ or refrigerant spray $[8,18,21]$. Both the precooling agents (ice and refrigerant spray) were used in studies by Vafaei et al. and Lathwal et al. [18,21]. Precooling interventions were compared to controls such as: topical anesthesia [8,18,20,21]; vibratory counter stimulation [18] or both topical anesthesia and counter stimulation [22] or none (no precooling, no topical, no counter stimulation) [19]. The duration of precooling injection site ranged between 60-120 seconds for ice group [19-22] and $5-10$ seconds for the refrigerant group $[8,21]$. The gauge of the needle used differed among included studies: 25-gauge [18,21], 26-gauge [8], 27-gauge [20,22]. Injection site also varied and was either maxilla $[18,20]$ or mandible only $[8,22]$ or both jaws $[19,21]$. Injection type varied from infiltration only [18,20]; block only $[8,21,22]$ and both infiltration and block [19].

\section{Effects of Precooling interventions before local anesthesia administration on subjective pain in children [primary outcome]}

The majority of included studies $(n=5)$ evaluated the reported subjective pain. The measure of scale used to evaluate subjective pain was VAS in these included studies [8,18-21]. The study by Aminabadi and Farahani did not evaluate the subjective pain [22].

Precooling versus Control (no topical anesthesia, no counter- stimulation): In the study by Bose et al., significantly lower VAS scores were reported for the ice precooling group than for the control group for both block injections (Z-score: -4.974; P value $<0.001$ ) as well as infiltrations (Z-score: -5.49; P value < 0.001) [19].

Precooling versus Topical anesthetic: Among the three studies comparing precooling versus topical anesthesia $[8,18,21]$, the study by Hameed et al. compared ice application with lignocaine spray [8], whereas two further studies (Vafaei et al. and Lathwal et al.) used both ice and refrigerant to compare against benzocaine topical anesthetic $[18,21]$. In the study by Hameed et al., Mean and SD values of the VAS scores were not provided directly and were calculated from the table. Lower VAS scores were observed in the ice precooling group (1.52 \pm 1.3 ) compared to the lignocaine topical anesthesia group $(2.14 \pm 1.34)(\mathrm{P}<0.05)$ [8]. The studies by Vafaei et al. and Lathwal et al., comparing precooling versus topical anesthetic, exhibited differences as well as similarities of results in terms of VAS scores. In the study by Vafaei et al., the VAS scores reported were significantly lower in topical anesthesia group (median VAS value -1) in comparison to precooling with either ice (median VAS value -2) or refrigerant (median VAS value -5) [18], contradictory, the study by Lathwal et al. reported significantly lower VAS scores for ice precooling group than refrigerant precooling or topical anesthesia group. The results may differ due to the different injection sites (infiltration in study by Vafaei et al. and block injections in study by Lathwal et al.). One similarity in both the studies (Vafaei et al. and Lathwal et al.) was that intergroup comparison revealed lower VAS scores in the ice precooling group than in the refrigerant precooling group [18,21].

Precooling + Topical anesthetic versus Topical anesthetic only: Lower VAS scores were exhibited in precooling $+20 \%$ benzocaine group $(4.22 \pm 1.27)$ in comparison to $20 \%$ benzocaine only group $(5.84 \pm 1.68)$, and difference was significant $(\mathrm{P}<0.05)$ [20]. 
Overall, among all the five studies evaluated for VAS score, four studies reported significantly lower VAS scores for precooling group [8,19-21], one study reported higher VAS scores in precooling group [18].

\section{Effects of Precooling interventions before local anesthesia administration on objective pain of child [secondary outcome]}

All the six included studies evaluated pain reaction of child with SEM scale [8,18-22]. Precooling versus Control (no topical anesthesia, no counter-stimulation): In the study by Bose et al., significantly lower SEM scores were reported for ice precooling group in comparison to control group for both block injections and infiltrations (z- value -3, -5.74, -2.23) (P-value .003, .000, .025) [19].

Precooling versus topical anesthetic: Among the three studies comparing SEM scores of precooling versus topical anesthesia $[8,18,21]$, the study by Lathwal et al. reported lower SEM scores for the ice precooling group, whereas the study by Vafaei et al. reported lower SEM scores for the benzocaine group, and the study by Hameed et al. reported no significant differences between ice precooling and topical anesthesia (lignocaine spray) group $[8,18,21]$.

Precooling + topical anesthetic versus topical anesthetic only: Significantly lower SEM scores were reported in precooling $+20 \%$ benzocaine group (4.06 \pm 1.32 ) in comparison to $20 \%$ benzocaine only group ( 5.44 \pm 1.79 . $)(\mathrm{P}<0.05)[20]$. Precooling + topical anesthetic versus topical anesthetic + counter-stimulation: Significantly lower SEM scores were reported in precooling + $20 \%$ benzocaine group (mean SEM-1.47) in comparison to $20 \%$ benzocaine + counter-stimulation group (mean SEM-2.85) $(\mathrm{P}<0.05)$ [22].

Among all 6 studies evaluated for SEM score, 4 studies reported significantly lower SEM scores in the precooling group [19-22], in a single study this difference was not significant [8], and one study reported higher SEM scores in the precooling group [18].

\section{Summary of evidence}

This systematic review evaluated subjective pain reported and objective pain evaluated when precooling was used as intervention prior to administering local anesthesia in children. Based on the available evidence, precooling is a viable option for reduction of pain during local anesthesia administration.

Limitations of this review: This review had several limitations. First, all 6 studies measured VAS and SEM, but mean and standard deviations were only presented in one study [20]. In all the other studies means and standard deviations were not mentioned directly and attempts to contact the authors failed. Hence, the pooling of data for a meta-analysis was not possible. Second, the injection site for local anesthesia administration and the needle gauge, was not standardized. Several studies evaluated block injections [IANB] only $[8,22]$, whereas other studies evaluated the combination of infiltrations and block injections $[18,19]$.

\section{CONCLUSIONS}

Based on the discussion following conclusions can be made:

1. The use of precooling as an adjunct (if not alternative) to topical anesthesia before local anesthesia administration can be an effective measure in reducing pain. Further studies are required to validate this observation.

2. Precooling with ice is more effective than with refrigerant spray.

3. Risk-of-bias is high in most of the studies. Hence, the quality of evidence is low.

\section{AUTHOR ORCIDS}

Sunny Priyatham Tirupathi: https://orcid.org/0000-0002-2593-0090

Srinitya Rajasekhar: https://orcid.org/0000-0002-1498-1618 


\section{AUHOR BOWHBHUIONS}

Sunny Priyatham Tirupathi: Conceptualization, Methodology, Writing - original draft, Writing - review \& editing

Srinitya Rajasekhar: Writing - review \& editing

FUNDING: There is no financial support and sponsorship to declare.

CONFLICT OF INTEREST STATEMENT: There are no conflicts of interest to declare

ACKNOWLEDGEMENTS: We affirm that we have no financial affiliation. We have no conflicts of interest.

\section{REFERENCES}

1. van Wijk AJ, Hoogstraten J. Anxiety and pain during dental injections. J Dent 2009; 37: 700-4.

2. Dasarraju RK, SVSG N. Comparative efficacy of three topical anesthetics on 7-11-year-old children: a randomized clinical study. J Dent Anesth Pain Med 2020; 20: 29-37.

3. Ujaoney S, Mamtani M, Thakre T, Tote J, Hazarey V, Hazarey P, et al. Efficacy trial of camouflage syringe to reduce dental fear and anxiety. Eur $\mathrm{J}$ Paediatr Dent 2013; 14: 273-8.

4. Melwani AM, Srinivasan I, Setty JV, D.R. MK, Pamnani SS, Lalitya D. A clinical comparative study between conventional and camouflaged syringes to evaluate behavior and anxiety in 6-11-year-old children during local anesthesia administration-a novel approach. J Dent Anesth Pain Med 2018; 18: $35-40$.

5. Liu Y, Gu Z, Wang Y, Wu Q, Chen V, Xu X, et al. Effect of audiovisual distraction on the management of dental anxiety in children: a systematic review. Int J Paediatr Dent 2019; 29: 14-21.

6. Chopra R, Jindal G, Sachdev V, Sandhu M. Double-blind crossover study to compare pain experience during inferior alveolar nerve block administration using buffered two percent lidocaine in children. Paediatr Dent 2016; 38: 25-9.

7. Meincken M, Norman C, Arevalo O, Saman DM, Bejarano T. Anesthesia onset time and injection pain between buffered and unbuffered lidocaine used as local anesthetic for dental care in children. Paediatr Dent 2019; 41: 354-7.

8. Hameed NN, Sargod SS, Bhat SS, Hegde SK, Bava MM. Effectiveness of precooling the injection site using tetrafluorethane on pain perception in children. J Indian Soc Pedod Prev Dent 2018; 36: 296-300.

9. Abbott K, Fowler-Kerry S. The use of a topical refrigerant anesthetic to reduce injection pain in children. J Pain Symptom Manage 1995; 10: 584-90.

10. Harbert H. Topical ice: a precursor to palatal injections. J Endod 1989; 15: 27-8.

11. Duncan JD, Reeves GW, Fitchie JG. Technique to diminish discomfort from the palatal injection. $\mathrm{J}$ Prosthet Dent 1992; 67: 901-2.

12. Kosaraju A, Vandewalle KS. A comparison of a refrigerant and a topical anesthetic gel as preinjection anesthetics: a clinical evaluation. J Am Dent Assoc 2009; 140: 68-113.

13. Jayasuriya NSS, Weerapperuma ID, Amarasinghe MGCK. The use of an iced cotton bud as an effective pre-cooling method for palatal anaesthesia: a technical note. Singapore Dent J 2017; 38: 17-9.

14. Wiswall AT, Bowles WR, Lunos S, McClanahan SB, Harris S. Palatal anesthesia: comparison of four techniques for decreasing injection discomfort. Northwest Dent 2014; 93: 25-9.

15. Bilsin E, Gungormus Z, Gungormus M. The efficacy of external cooling vibration on decreasing the pain of local anesthesia injections during dental treatment in children: a randomized controlled study. J Perianesth Nurs 2020; 35: 44-7.

16. Bhadauria US, Dasar PL, Sandesh N, Mishra P, Godha S. Effect of injection site pre-cooling on pain perception in patients attending a dental camp at life line express: a split mouth interventional study. Clujul Med 2017; 90: 220-5.

17. Johnson J, Primosch RE. Influence of site preparation 
methods on the pain reported during palatal infiltration using the wand local anesthetic system. Am J Dent 2003; 16: 165-9.

18. Vafaei A, Rahbar M, Dadkhah R, Ranjkesh B, Erfanparast L. Children's pain perception and behavioral feedback during local anesthetic injection with four injection site site preparation methods. Maedica 2019; 14: 343-9.

19. Bose S, Garg N, Pathivada L, Yeluri R. Cooling the soft tissue and its effect on perception of pain during infiltration and block anesthesia in children undergoing dental procedures: a comparative study. J Dent Res Dent Clin Dent Prospects 2019; 13: 159-65.
20. Ghaderi F, Banakar S, Rostami S. Effect of precooling injection site on pain perception in pediatric dentistry: "a randomized clinical trial". Dent Res J 2013; 10: 790-4.

21. Lathwal G, Pandit IK, Gugnani N, Gupta M. Efficacy of different precooling agent and topical anesthetics on the perception during intraoral injection: a comparative clinical study. Int J Clin Pediatr Dent 2015; 8: 119-22.

22. Aminabadi NA, Farahani RM. The effect of pre-cooling the injection site on pediatric pain perception during the administration of local anesthesia. J Contemp Dent Pract 2009; 10: 43-50. 